\title{
Political Parties, the 1999 Nigerian Constitution and the 2011 General Elections
}

\author{
By E.S. Nwauche*
}

\begin{abstract}
Given the critical role that political parties play in constitutionalism democratization and development, the proper design and functioning of political parties is crucial as democracy and constitutionalism is deepened in Nigeria. Using the 2011 Nigerian general elections as a factual context this paper critically examines four propositions that significantly enhance the role of Nigerian political parties in the country's democratic consolidation within the framework of the Constitution of the Federal Republic of Nigeria 1999. The first proposition is that the present design of the role of Nigerian political parties in electoral competition is not reflective of the peculiarities of Nigeria while the second proposition argues the importance and need for a more effective regulation of political parties. The third and fourth propositions concern the judiciary. While the third proposition is that the judiciary must continue to engage in an unlimited judicial review of the constitutions of political parties, the fourth proposition requires a principled adjudication of electoral disputes.
\end{abstract}

\section{Introduction}

Effective political parties are fundamental to the success of the democratization project in Nigeria. Without viable political parties democracy is doomed in Nigeria. "By their very nature, political parties are representative institutions that endow regimes with legitimacy; provide ideologies that represent social, economic and political interests; and produce leaders who through democratic elections form the machinery of government (from parliament to the political executive) or opportunities for political participation, or a combination of all three"1.

In the aftermath of the 2007 general elections, the federal government established a 22 Member Electoral Reform Committee charged with examining “...the entire electoral process with a view to ensuring that we raise the quality and standard of our general elections and

* nwauche@hotmail.com.

1 See IDEA Political Parties in Africa: The Challenge of Sustained Multiparty Democracy 20. Available at http://www.idea.int/publications/pp_africa/ (Accessed 28 November 2013). 
thereby deepen our democracy"2 This was understandable since that election was regarded as one of the worst in the nations electoral history. ${ }^{3}$ The Electoral Act $2010^{4}$ is a direct response to the Uwais Report published in 2008.Even though many aspects of the Report influenced the 2010 Electoral Act there are a number of aspects of the Uwais Report that were abandoned including extensive recommendations concerning political parties. Certain amendments to the Constitution of the Federal Republic of Nigeria $1999^{5}$ were also a reaction to the Uwais Report. It was felt in many quarters that the 2010 Electoral Act and the amended parts of the 1999 Constitution provided an adequate legal framework for the 2011 general elections.

The 2011 general elections were conducted on the framework of the 2010 Electoral Act. The assessment of many external and internal observers was that the 2011 elections was better than the 2007 general elections. For example The International Crisis Group ${ }^{6}$ stated that "With the April 2011 general elections Nigeria may have taken steps towards reversing the degeneration of its previous elections...After three flawed elections-1999, that heralded the Fourth Republic, 2003 and 2007, the last being the most discredited-the 2011 polls were critical for Nigeria's fledgling democracy and overall political health." 7 The European Union Election Observation Mission to Nigeria 2011 stated that: “...the 2011 elections marked an important improvement compared to all polls observed previously by the European Union in Nigeria. ${ }^{8}$ Other external observers agreed with this favourable assessment. ${ }^{9}$ Internal observers like the

2 Report of the Electoral Reform Committee, Vol.1 Main Report, December 2008. Available at www.resourcedat.com/wp-content/uploads/2012/01/Uwais-Report-on-Electoral-Reform.pdf (last accessed on 27 November 2013). (Hereafter Uwais Report).

3 See Domestic Election Observation Group "An election programmed to Fail”: Our monitors throughout the country noted and documented numerous lapses, massive irregularities and electoral malpractices that characterised the elections in many states. Based on the widespread and far-reaching nature of these lapses, irregularities and electoral malpractice, we have come to the conclusion that on the whole, the elections were a charade and did not meet the minimum standards required for democratic elections. We therefore reject the elections and call for their cancellation." The Guardian (Nigeria), Wednesday, 25 April 2007.

4 Hereafter 2010 Electoral Act.

5 Hereafter 1999 Constitution (as amended).

6 International Crisis Group, "Lessons from Nigeria's 2011 Elections", African Briefing No. 81, http:// www.crisisgroup.org/en/regions/africa/west-africa/nigeria/B81\%20Lessons $\% 20$ from $\% 20$ Nigerias\% 202011\%20Elections.aspx (last accessed on 27 November 2013).

7 Ibid at p. 1.

8 Available at http://www.eueom.eu/files/pressreleases/english/press-release-31052011_en.pdf (last accessed on 27 November 2013).

9 See for example the assessment of Johnnie Carson, US Assistant Secretary for African Affairs:

"Nigeria conducted its most successful and credible elections since its return to multiparty democracy in 1999. (...)The April 2011 elections were clearly another step forward in Nigeria's continuing democratization process, but more work has to be done to improve Nigeria's electoral procedures and more importantly to strengthen the country's democratic institutions and governance." The Guardian (Nigeria), Friday 13 April, 2012, p. 10. 
Nigerian Bar Association also agreed. ${ }^{10}$ On the other hand there were many problems as the reports of the election observers and other commentators reveal. ${ }^{11}$ In sum, there were logistical problems including a fairly compromised voters registration exercise; padded voters register; multiple and under aged voting; faulty biometric scans; contentious political party primary elections; inflated election results and a fatal post-election violence in the Northern states of Nigeria consequent on the announcement of the results of the presidential election.

The results of the 2011 general elections indicated the whittling down of the dominance of the Peoples Democratic Party (PDP) which after the 2007 general elections controlled the presidency 27 of the 36 states of the country and two thirds majority in the Nigerian senate (the upper house of the National Assembly). The results of that election show that the PDP lost control of five states; lost the two thirds majority in the Nigerian senate and lost its majority in the House of Representatives. The Action Congress of Nigeria (ACN) and the All Nigeria Progressive Party (APGA) gained control of a number of states previously controlled by the PDP. In the National Assembly 72 senators lost their seats while 260 members of the House of Representatives also lost their seats. It can be safely concluded that the 2011 elections was an agent of change ${ }^{12}$ albeit a muted one.

The performance of political parties did not show any remarkable improvement in the electoral penetration of many of the 70 registered political parties. Many of these parties did not contest any of the elections and in fact in some instances behaved as annexes of the PDP. ${ }^{13}$ Four major issues relevant to this paper can be said to characterize the 2011 general elections. The first is abject performance of many of Nigeria's political parties. The second issue is the apparent inability of the Independent National Electoral Commission (INEC) to effectively regulate Nigerian political parties. Thirdly there has been widespread complaint of a lack of internal democracy in the political parties especially in the nomination and sponsorship of candidates. Finally the Nigerian Supreme Court has in a number of election petitions shut out the substantive determination of electoral disputes by strictly upholding the constitutional time limit for election petitions. These four issues provide the general background of this paper. Given the critical role that political parties play in constitutionalism democratization and development, the proper design and functioning of political parties is crucial as democracy and constitutionalism is deepened in Nigeria.

10 See Joseph Bodunrin Daudu San, "Nigerian Bar Association on the Conduct of the 2011 General Election" 20 April 2011. Available at www.saharareporters.com/press-release/Nigerian-bar-associ ation-conduct-2011-generalelection (last accessed on 27 November 2013): "INEC must be congratulated for conducting a transparently credible election so far".

11 See for example Peter M. Lewis, Nigeria Votes: More Openness, More Conflict, Journal of Democracy, 22(4) (2011), p. 60.

12 See generally Nic Cheesman African Elections as Vehicles of Change, Journal of Democracy 21(4) (2010), p. 139.

13 A few months to the April 2011 presidential elections 46 of the registered parties adopted President Goodluck Jonathan who won the 2011 presidential election as their candidate. 
The theoretical assumptions of this paper spring from the widespread agreement on the role of political parties in emerging democracies especially in the third world and host of mechanisms that can assist political parties in this regard. While there is unanimity in the recognition of the importance of political parties in democratic transitions and consolidation $^{14}$, there is also a measure of agreement that party institutionalization is also critical to democratic consolidation. Randall and Svasand ${ }^{15}$ define party institutionalization as the process by which parties becomes established in terms of integrated patterns of behavior attitudes and culture. ${ }^{16}$ The authors make a further distinction between the internal and external aspects of this process and argue that while the internal aspect relate to developments within the party, the external aspects deal with the party's relationship with the society in which it operates. ${ }^{17} \mathrm{~A}$ further clarification is advanced by the authors that within these aspects of the process there are structural and attitudinal components. Thus while the structural aspect of the internal dimension is systemness the attitudinal dimension of the internal aspect is value infusion which interrogates the ability of a party to develop its own culture which contributes to its identity. For the external aspects of party institutionalization the structural dimension is the party's capacity for significant decisional autonomy. The attitudinal aspect of the external dimension is reification which relates to the public image of the political party. It is within this theoretical framework that this paper argues that the four propositions it examines further the institutionalization of Nigerian political parties and Nigeria's democratic consolidation. The choice of the four propositions is not regarded as an exhaustive answer to the problems of Nigerian political parties but rather a choice of measures that are more likely to make significant impact. It is acknowledged that there are other issues in party institutionalization such as access to media; internal organizational structures; interface with traditional authorities and gender diversity that can also impact the institutionalisation of political parties in Nigeria.

Using the 2011 Nigerian general elections as a factual context this paper critically examines four propositions that significantly enhance the role of Nigerian political parties in the country's democratic consolidation within the framework of the Constitution of the Federal Republic of Nigeria 1999. The first proposition is that the present design of the role of Nigerian political parties in electoral competition is not reflective of the peculiarities of Nigeria while the second proposition argues the importance and need for a more effective regulation of political parties. The third and fourth propositions concern the judiciary. While the third proposition is that the judiciary must continue to engage in an unlimited judicial review of the constitutional statutory and internal obligations of political parties, the fourth proposition

14 See Christopher Clapham, Democratisation in Africa: Obstacles and Prospects, Third World Quarterly, 14 (1993),p. 423.

15 Vicky Randall and Lars Svasand Party Institutionalisation in New Democracies, Party Politics, 8(1) 2002 , p. 5.

16 Ibid at p. 12.

17 Ibid. 
requires a principled adjudication of electoral disputes. In the context of the Randall and Svasand paradigm the first proposition engages the internal aspects of party institutionalization while the second third and fourth propositions deal with external dimensions of party institutionalization.

The factual context of this paper provides rich evidence largely absent in the literature of the institutionalisation of political parties in Nigeria through a multi-disciplinary approach of discussing legal issues within broader political theory.

This paper believes that Nigeria is emblematic of the widespread agreement that institutionalizing political parties can contribute to democratic consolidation. Even with its numerous problems the infancy of the democratic process and events of the 2011 elections reveal a considerable potential that Nigeria's democratic consolidation can be enhanced by institutionalized political parties a fact which the four propositions argued in this paper seeks to advance.

\section{The Design of Political Parties in a Federal Nigeria}

In this part of the article I examine three aspects of the first proposition that the present design of Nigeria's political parties is not sufficiently reflective of the peculiarities of Nigeria. I argue that while the present proliferation of political parties should be encouraged, Nigeria must move towards public funding of political parties and the adoption of proportional representation.

Given Nigeria's multi-ethnic multi-religious composition, and the history of electoral competition, it is not surprising that it is strongly felt that the existence of many parties have led to their fractious performance and the emergence of a dominant party. It is also felt that in order to ensure that Nigeria does not become a one party state the number of political parties must be reduced to ensure that there are larger parties that are effective and provide credible alternatives ${ }^{18}$ to dominant parties. For example the Uwais Report points out that "the relatively freest elections in Nigeria were conducted under a two party system between 1989 and 1993 "19

Nigeria's political history has been one in search of 'national parties'. Nigeria's second republic (1979-1983) saw the emergence of five political parties from fifty political associations that applied for registration as part of the transition program that ended military rule in 1979. The registered political parties were adjudged to be parties with national spread in outlook membership and infrastructure. In this regard, it is therefore not surprising that in the aborted 1989 Constitution of the Federal Republic of Nigeria ${ }^{20}$ s. 220(1)d provided for only

18 See Nicholas van de Walle, Presidentialism and Clientelism in Africa's Emerging Party Systems, Journal of Modern African Studies 41(2) (2003), p. 297; Michael Bratton, The Alternation Effect in Africa Journal of Democracy 15(4) (2004), p. 147.

19 See note 2.

20 The 1989 Constitution of Nigeria was adopted as part of the Transition Program of the Rtd. General Ibrahim Babaginda but was never operational. 
two political parties in Nigeria. ${ }^{21}$ The 1989 Constitution concretised aspects of a transition program instituted after the military coups of 1984 and 1985. That program included a Political Bureau that sought to synthesise the direction of Nigeria's democratisation. The Political Bureau recommended a two party system which was to develop gradually over time. The then electoral umpire- the National Electoral Commission (NEC)- accepted applications for registration of political parties as soon as the Federal Military Government lifted the ban on political activities in May 1989. Out of the thirteen political associations that submitted their applications, NEC recommended six political associations for registration. The Armed Forces Ruling Council eventually imposed two grassroots parties on the country - the Social Democratic Party (SDP) and the National Republican Convention (NRC). These two parties fought the 1993 general elections which was aborted after the June 121993 presidential elections. An infamous civilian arrangement- the Interim National Government- that succeeded General Ibrahim Babangida lasted till December 1993 when the military assumed power. As part of its transition program the General Sani Abacha led government again registered five political parties out of a total of eighteen political parties that applied for registration. On the death of General Abacha in 1998, the new military government of Abdusallam Abubakar cancelled the registration of the political parties.

The preference for national parties has been an avowed objective of the fourth republic. At its start in 1999, nine political parties were provisionally registered pursuant to the 1999 Constitution. Permanent registration was contingent on winning at least $10 \%$ of the votes in at least 24 states in the 1999 local government elections with the benefit of contesting the subsequent state and federal elections. The results of the 1999 general elections resulted in only three parties- the Peoples Democratic Party (PDP; the All Peoples Party (APP) and the Alliance for Democracy (AD) being registered. The clamour for more parties based on the right to freedom of association guaranteed by chapter four of the 1999 Constitution went unheeded forcing a number of political associations to turn to Nigerian courts for relief in liberalizing the conditions for the recognition and registration of political parties. In INEC $v$ $M_{u s a^{22}}$ the Supreme Court struck down some guidelines for the registration of political parties made pursuant to the Electoral Act 2001 by the Nigerian Electoral Agency (INEC) as well as some provisions of the Electoral Act 2001. The Court held that the only relevant eligibility requirements were first those found in s 222 of the 1999 Constitution $^{23}$ and secondly a number

21 See Tunde Adeniran, The Two-Party System and the Federal Political Process, Publius 21 (1991), p. 31.

22 [2003] FWLR (pt 145) 729. Hereafter Musa.

23 S. 222 of the 1999 Constitution provides that "No association by whatever name called shall function as a party, unless - (a) the names and addresses of its national officers are registered with the Independent National Electoral Commission; (b) the membership of the association is open to every citizen of Nigeria irrespective of his place of origin, circumstance of birth, sex, religion or ethnic grouping; (c) a copy of its constitution is registered in the principal office of the Independent National Electoral Commission in such form as may be prescribed by the Independent National Electoral Commission; (d) any alteration in its registered constitution is also registered in the principal office of the Independent National Electoral Commission within thirty days of the making of such alteration 
of administrative procedural or evidential INEC guidelines as well as provisions of the Electoral Act 2001 that did not enlarge the requirements in s. 222 of the Constitution. The impugned INEC guidelines that were substantive in the sense that they added to the requirements in $\mathrm{s}$ 222 of the 1999 Constitution as well as provisions of the Electoral Act in the same stead were struck down since they raised the threshold of compliance with registration requirements. A comparison of the constitutional requirements and the impugned INEC guidelines and provisions of the Electoral Act reveal that they are similar even though the INEC guidelines are lighter than the constitutional requirements. For example while section 222 (a) of the 1999 Constitution requires that the names and addresses of national officers should be submitted to INEC, guideline 3(a) of the INEC Guidelines requires that the names residential addresses and States of origin respectively of the members of its National and State Executive Committees and records of proceedings of the meetings where these officers are elected. Furthermore the Supreme Court upheld section 72(2)g and 74(6) of the Electoral Act which imposes a fee for registration which has no constitutional counterpart declaring that such a requirement is administrative. It is plausible to conclude that the court was interested in curtailing the powers of INEC in the registration of political parties; reducing its powers in this regard to that of a mere administrative agency that is to provide evidence of registered political parties. The court's intervention was a liberal interpretation of the freedom of association as supportive of the proliferation of political parties. It was clear to the Court that the additional requirements imposed by INEC were exclusionary. It was not surprising that while only three parties were recognized at the end of the registration exercise that led to Musa, over thirty five parties post Musa contested the 2003 general elections. The parties have increased since then because over 50 registered parties contested the 2007 and 2011 elections. There are presently 63 registered political parties in Nigeria and there are many who consider that this is simply too much. An important question at this point is whether the proliferation of political parties is good for Nigeria's budding democracy? Since Nigeria's democratic transition is in its infancy a proliferation of political parties could foster the ethic of deliberation negotiation and consensus that are crucial for democratic consolidation. Political parties aggregate similar interests and should provide alternative choices for Nigerians at all levels. There is a very strong chance that a large number of political parties would mobilise the civic responsibilities of Nigerians and thus engage their democratic participation. It is inevitable that some political parties could become rent seekers extracting value by their mere existence from the State. It should not be difficult to devise strategies to identify and deal with such parties. One mechanism used in Nigeria by INEC is the deregistration of political parties which also has the potential of working towards the evolution of 'national parties'. In the aftermath of the 2011 elections INEC

(e) the name of the association, its symbol or logo does not contain any ethnic or religious connotation or give the appearance that the activities of the association are confined to a part only of the geographical area of Nigeria; and (f) the headquarters of the association is situated in the Federal Capital Territory, Abuja.". 
proceeded to deregister certain political parties ${ }^{24}$ in accordance with the powers granted by s. 78(7) of the 2010 Electoral Act which enables INEC to deregister a political party that breaches any of the requirements of registration or fails to win the presidential or governorship election or a seat in the National or State Assembly. While the first condition provides INEC with a functional administrative power to assess compliance with registration requirements, the second requirement that a political party should win a legislative or executive seat to continue in existence strikes at the root of the mission of political parties as aggregates of opinion and public policy. A party that does not win a seat in a general election may do in the next general election. Furthermore this requirement assumes that the elections on which the political parties are to be judged are indeed free and fair. Nigeria's electoral history is fraught with irregularities that contribute in the exclusion of certain parties. It is therefore clear that the requirement of wining an executive or legislative seat should be replaced with a new requirement of functionality which should require an active engagement of political parties as significant participants in the political process.

It is often felt that a proliferation of political parties predispose many of them to become instruments of religious and ethnic politics ${ }^{25}$ and those 'national' parties somehow prevent this from happening. The history of Nigerian political parties reveals that ethnic regional and religious issues are part of the numerous challenges that political parties must deal with. Even though the 1999 Constitution requires every political party to be open to all Nigerians irrespective of place of origin, circumstance of his birth, sex, religion or ethnic grouping, ${ }^{26}$ this cannot mean that a party that has a preponderant membership of a certain faith is 'illegal' in a country that recognizes the freedom of religion. It should not be wrong for a political party to focus its attention on specific regions states or local governments in the country where it may have a comparative advantage efficiency and impact. In addition a political party may be formed to promote certain issues which may in turn geographically localize the party. Even though these local and regional parties can surely complement 'national' parties, the preference for 'national' parties is tied to Nigeria's struggle between integration and accommodation in its political history. ${ }^{27}$

I shall now turn to consider the second aspect of the first proposition about the design of political parties in Nigeria and it is the importance of public funding of political parties as a critical part of the identity and autonomy of political parties. Political parties require funding

24 The affected parties are Democratic Alternative (DA), National Democratic Council (NDC), National Action Council (NAC), Masses Movement of Nigeria (MMN), National Unity Party (NUP), Nigeria People Congress (NPC) and Nigeria Elements Progressive Party (NEPP).

25 See for example Shaheen Mozaffar, James $R$ Scarritt and Glen Galaich Electoral Institutions, Ethnopolitical Cleavages and Party Systems in Africa's Emerging Democracies, American Political Science Review 97(3) (2003),p. 379.

26 See s. 222 (b) of the 1999 Constitution as amended.

27 See generally John Boye Ejobowah Integrationist and accommodationist measures in Nigeria's constitutional engineering: Successes and failures, in: Sujit Choudry (ed), Constitutional Design for Divided Societies: Integration or Accommodation, Oxford 2008, p. 233. 
in their formation and sustenance. It is usually felt that being an aggregate of personal interests members of a political party ought to finance their party and that the state ought not to be involved. Political parties fulfill a public good in producing policy and governance alternatives that enhance the choice of the people in true democratic spirit. There is therefore a great need for public funding of political parties so that they can be formed and sustained.

The need to ensure and assist fledging political parties in the fourth Republic (1979-1983) may have resulted in the provisions of s.228 (c) of the 1999 Constitution granting the National Assembly powers to make a law for an annual grant to INEC for disbursement to political parties on a fair and equitable basis to assist them in the discharge of their functions. In consequence the 2002 Electoral Act made certain provisions approving the disbursements of grants to political parties. ${ }^{28}$ The 2006 Electoral Act continued this tradition by providing in s.90 that the National Assembly may approve a grant for disbursement to political parties contesting elections. In addition s. 91 empowered the National Assembly to make an annual grant to the Commission for disbursement to political parties on the criterion that $10 \%$ of the grant shall be shared equally among all registered political parties and the remaining $90 \%$ shared amongst parties with seats in the National Assembly in proportion to their seats. There is no doubt that these two provisions encouraged rent seeking associations to seek registration as political parties. The 2010 Electoral Act has no provision for the public funding of political parties bringing to the fore a reexamination of the reasons for public grants to political parties. While it is again conceded that the grants may be subject to abuse, this would appear to reflect the inability of INEC to effectively regulate political parties and ensure that they are accountable for public funds. Even now, the need to assist political parties in their operations has not lessened, except for political parties who occupy the government houses at the state and federal level.

It is instructive that only the parties in power in some states in Nigeria- the Action Congress of Nigeria (CAN); the Congress of Peoples Change (CPC); the Labour Party (LP) and the All Nigeria Peoples Party (ANPP) are the ones who succeeded in winning federal and state legislative and executive seats in the 2011 general elections. As yaw Saffu explains: "The

28 Sections 80-81 of the 2002 Electoral Act provided as follows: "80. (1) The National Assembly may approve a grant for disbursement to the political parties contesting elections after the coming into force of this Act. (2) The grant approved in pursuance of subsection (1) of this section shall be made to the Commission which shall distribute the grant to the Political Parties in the following manner. (a) $30 \%$ of the grant shall be shared equally among the registered political parties participating in respect of a general election for which the grant has been made. (b) the remaining $70 \%$ of the grant shall be shared among the Political Parties, after the result of the elections have been known, in proportion to the number of seats won by each party in the National Assembly. 81. (1) Notwithstanding the provisions of this Act, the National Assembly may make an annual grant to the Commission for distribution to the registered Political Parties to assist them in their operation. The Commission shall distribute such grant as follows:-

(a) $30 \%$ of the grant shall be shared equally among all the registered political parties. (b) the remaining $70 \%$ of the grant shall be shared among the registered political parties in proportion to the number of seats won by each party in the National Assembly.". 
difference between the amounts of money available to governing and opposition parties tends to be far larger in Africa than elsewhere. This difference in fortune cannot be explained in ideology, policies, or the social bases of party support. Instead the primary explanation is incumbency." ${ }^{29}$ To deny public funding to the other parties is to assume that there is a level playing field for them. Supervised public funding enables hitherto weak parties to develop their potential and become credible alternatives. Public funding reduces the ability of 'moneybags' to hijack political parties who without public funding will resort to private finances.

It is interesting to note that a number of other African States publicly fund political parties. For example section 236 of the 1996 Constitution of South Africa provides that to 'enhance multi-party democracy, national legislation should provide the funding of political parties participating in national and provincial elections on an equitable or proportional basis. ${ }^{30}$ It is also interesting to note how in the Zimbabwean case of United Parties $v$ Minister of Justice Legal and Parliamentary Affairs ${ }^{31}$ the Zimbabwean Supreme Court struck down legislation that denied state funding to political parties with fewer than fifteen members of parliament because this meant that only the ruling party was entitled to funding. The Court held that this is an unfair system of funding because it set a high threshold and thus violated the political parties' freedom of expression. The Court pointed out that in poor societies, state funding is critical because private funding is not available or inadequate necessitating a lower threshold.

I turn now to the third aspect of the first proposition which is the need to introduce proportional representation as a key step in the design of how political parties interface with the electoral system. In a country in which power is a zero sum game majoritarian representation results in a frenetic contestation for power while proportional representation could encourage political parties to canvass for votes- and institutionalize- to meet a performance threshold. On the other had while majoritarian representation could ensure a direct linkage and accountability between a representative and the constituents, ${ }^{32}$ proportional representation could compromise the importance of individual preference and choice by voters. Perhaps the best design is a combination of proportional and majoritarian rules of representation which is what Uwais Report recommended by a combination of the first-past-the -post and modified proportional representation at federal state and local levels. ${ }^{33}$ Unfortunately the 2010 Electoral Act would have none of a mixed system. It is important therefore to examine the nature of the proposal made by the Uwais Report. The mixed system would entail creating an additional $30 \%$ of the existing legislative seats in the National State and local government levels for the purposes of proportional representation. A performance threshold shall then be established which is the number of votes cast in the First-Past-The-Post election divided by the number

29 See Yaw Saffu, The Funding of Political Parties and Election Campaigns in Africa, in: IDEA Funding of Political Parties and Election Campaigns, 2003, p. 25.

30 See the Public Funding of Represented Political Parties Act 103 of 1997 which gives effect to s. 236.

311998 (2) BCLR 224 (ZS).

32 See Joel Barkan, Elections in Agrarian Societies, Journal of Democracy 8 (1995),p. 106.

33 See paragraph 2.3.1 of the Uwais Report, note 2, p. 52. 
of available proportional representation seat. Political parties shall then nominate for proportional representation at least $30 \%$ female candidates and $2 \%$ physically challenged candidates for legislative elections. Political parties that win up to $70 \%$ of the seats in an election conducted under the First-Past-The-Post election shall not be eligible to benefit from the proportional representation. The criterion, for the production of the party list was to be included in an amended electoral act. The need for proportional representation is long overdue and would greatly assist the growth and performance of political parties. Of importance is the production of the party list and it is suggested that list should at least contain members who are the party's electoral candidates.

To sum up this part of the article it is important to stress that the continued proliferation of political parties, the public funding of political parties and proportional representation will significantly enhance Nigeria's multi-party democracy. These three measures point to an enhanced public status of political parties in Nigeria. They cannot be left unregulated and it is to the need for their effective regulation that the next part examines.

\section{An Effective Regulation of Nigerian Political Parties}

This part of the article examines the second proposition that there must be an effective administrative regulation of Nigerian political parties by the Independent National Electoral Commission (INEC) if they to fulfill their mission as private institutions whose activities have enormous public consequences and contribute to democratic consolidation. In this regard section 224 of the 1999 Constitution requires that the aims of Nigerian political parties shall conform to the fundamental objectives and directive principles of state policy contained in chapter II of the constitution. These objectives and directive principles of state policy contain aspirational values and standards in the political social economic cultural educational fields as well as the obligation of the mass media, national ethics and duties of citizens. These values and standards govern all branches of government entrusted with the exercise of political powers. In sum therefore Nigerian political parties are conceived as public institutions if they are to be guided by these values and standards. Furthermore there is an express requirement for the internal democracy in political parties since their constitutions must provide for the periodic election of principal officers and members of the governing body of political parties on democratic basis. ${ }^{34}$ Even if there was no such express requirement, the 1999 constitution recognise democracy and social justice as Nigeria's foundational value. It is plausible to require political parties to voluntarily comply with the fundamental objectives and directive principles of state policy since they are not justiciable. ${ }^{35}$ However since the oversight functions of INEC over political parties as set out in the third schedule to the 1999 constitution mandates INEC to 'monitor the organization and operation of political parties, including their finances

34 See s. 223 (1) (a) of the 1999 Constitution.

35 See s. 6 (6) (c) of the 1999 Constitution. 
conventions congresses and party primaries ${ }^{36}$ it is clear that INEC has a duty to ensure that political parties conform to the fundamental objectives and directive principles of state policy.

The monitoring powers of INEC empower her to keep records of the activities of all registered political parties. ${ }^{37}$ Furthermore, INEC is also empowered to attend and observe any political party convention congress or meeting convened for the purpose of electing members of its executive committees or other governing bodies; nominating candidates for election at any level and approving a merger with any other registered political party. ${ }^{38}$ While there is no extensive evidence of how INEC approached this function in respect of the 2011 general elections, it is safe to state that INEC's approach to the activities of political parties is based on the voluntary compliance of political parties with their constitutional and statutory obligations. For example in the run up to the 2011 general elections INEC assisted the political parties to develop the Nigeria Political Parties Code of Conduct $2011 .{ }^{39}$ On the $8^{\text {th }}$ of March 201146 (Forty-Six) political parties signed the Code of Conduct with the notable exception of PDP that consigned the Code to irrelevance. Throughout the campaign period and the election, nothing was heard of the Code and fidelity to its terms by the political parties. Even at that, the content of the Code is indicative of a credible blueprint for effective regulation of political parties. For example paragraph 1-5 of the first part of the Code titled 'Rule of Law' is important in this regard because it provides that:

1. All political parties, their leaders, members and supporters, and candidates, shall adhere to all existing laws, rules and regulations partaking to elections, and the conduct of political parties, especially the elections guidelines established by INEC through the authority of the Electoral Act, 2010 (as amended), as well as provisions of the extant constitution of the Federal Republic of Nigeria, and shall do nothing whatsoever; individually or collectively to undermine, flout, disrespect or circumvent them.

2. Every political party shall provide equal opportunity to qualified persons to participate in electoral activities. In this regard political parties have the right and freedom to put forward their views to the electorate without hindrance; further, all political parties are enjoined at all times to uphold the rights and freedom of the Nigerian people, as guaranteed by law.

3. All political parties shall ensure, and practice internal party democracy. In this context, political parties shall, in the process of election or selection of their officers at various levels, adhere strictly to the provisions of their parties' constitution.

36 Article 15 (c) of the Third Schedule to the Constitution.

37 See s. 86(1) of the 2010 Electoral Act. S. 86 (3) and (4) empowers INEC to seek clarification and information on any activity of a registered political party as well as issue directives to a registered political party. Failure to carry out any lawful directive of INEC is regarded as a criminal offence and renders the political party liable on conviction to a fine of N500,000.00.

38 See s. 85(1) and (2) ibid.

39 Available at www.elombah.com/index.php?option $=$ com_content\&view $=$ article\&id $=5650$.nigeria-p olitical (last accessed on 27 November 2013). 
4. No political party shall engage in violent activates or intimidation of any kind, as a way of demarcating its strength or supremacy. Accordingly, all political parties shall publicly condemn any form of political violence or intimidation in its entire ramification.

5. It shall be the sacred and binding duty of political parties to ensure strict compliance with this Code of Conduct and assist the security agencies and electoral officials in apprehending and sanctioning their members who attempt to, or flout the provision of the Code, the Electoral Act and or INEC electoral guidelines. Political Parties shall co-operate with other stakeholders in developing further compliance and monitoring mechanisms to ensure the full effect of this code.

Other issues in the Code include campaign issues; election day issues; post-election issues; and party finance. The implementation monitoring and enforcement of the Code is the responsibility of the Inter-Party Advisory Committee (IPAC) which is constituted by single representatives of registered political parties as well as a representative of INEC. The duties of IPAC include to observe and monitor the implementation of the Code; identify, investigate and sanction violation of the code of conduct by any political party; receive complaints and investigate the veracity of the claims and impose appropriate sanctions; resolve dispute between two or more political parties arising from misunderstanding and/or breach of the Code; recommend remedies to INEC after its investigation and develop and recommend proposals to the Commission that will enhance the capacity of political parties. It is easy to imagine how an enforced Code of Conduct would have significantly improved the conduct of the 2011 general elections.

The other major function of INEC is financial regulation and there is mixed evidence of the exercise of its functions. On the positive side INEC evaluated the financial dealings of political parties which include auditing and publishing a report on detailed annual statement of assets and liabilities and analysis of its sources of funds and other assets, together with a statement of its expenditure. ${ }^{40}$ For the first time in its history on the $1^{\text {st }}$ of April 2012 INEC published an executive summary of external auditor's report of the accounts of the sixty three registered political parties. ${ }^{41}$ On the other hand, INEC has not been able to effectively monitor campaign expenses. In this regard INEC is empowered enforce the limit of individual and group contribution to political parties. ${ }^{42}$ In this regard, section 93(2) of the 2010 Electoral Act requires the disclosure by a political party of all monetary and other forms of contribution received by the party and the names and addresses of any person that contributes in excess of

40 See s. 89 of the 2010 Electoral Act.

41 See http://www.inecnigeria.org/?inecarticle=inec-publishes-audited-accounts-of-political-parties (last accessed on 27 November 2013).

42 See s. 90 of the 2010 Electoral Act. It would appear that the limit of the contribution is N1,000,000.00. 
1 million naira. ${ }^{43}$ In addition the financial oversight of INEC also extends to election expenses for political parties. While there are limits for individuals tied to the nature of their campaign, ${ }^{44}$ the political party expenses are to be determined by INEC in conjunction with the political parties after the submission of an audited return by the political party. ${ }^{45}$ The audited return shall be published in 2 national newspapers ${ }^{46}$ and be available for public inspection. ${ }^{47}$ It is important to note that no such audited return was made to INEC or published after the April 2011 general elections. Commenting on the limits to election expenses well before the April 2011 general elections, Osita Okechukwu argues that the framers of the 2010 Electoral Act were clever by half, limiting only the expenses of the candidate, with no reference to the expenditure of the political party, associates or government, in the case of incumbents. ${ }^{48}$ It is therefore plausible that even if the expenses of a candidate and the political parties are limited the same cannot be said of numerous support groups.

A general assessment of the oversight functions of INEC indicate that the Commission has considerable powers of regulation but is deficient in the implementation of these powers. For example the publication of a summary of the annual accounts of INEC in newspapers instead of on the INEC website is evidence of careless interpretation of its oversight mandate. Another example of the tardiness of INEC is the obligation imposed by s. 226(1) of the 1999 Constitution that requires INEC to prepare and submit an annual report of the accounts and balance sheet of every registered political party to the National Assembly. Rather than depend on the report of external auditors of political parties, the provisions of s. 226(2) of the 1999 Constitution enable INEC to engage an independent evaluation to determine whether proper books of account and proper records have been kept by political parties. It would appear that INEC does not strictly enforce compliance by members of the constitution of political parties. It is interesting to draw attention to the recent judgment of Abuja High Court in Ambassador

43 There are certain groups that cannot make donations to Nigerian political parties. Thus s. 38 (2) of the Companies and Allied Matters Act provides that "A company shall not have or exercise power either directly or indirectly to make a donation or gift of any of its property or funds to a political party or political association, or for any political purpose." See M.E Ekpo, Corporate Gifts for Political Purposes: An Analytical Exposition of s. 38 (2) of the Companies and Allied Matters Act 1990, Calabar Law Journal V(1) (2001), p.80.

44 See s. 91 of the 2010 Electoral Act. The expenses for presidential candidates is NGN1,000,000,000.00 (Approx.USD6.25 $\mathrm{m}$ at a exchange rate of 1USD to NGN160).

45 See s. 92 of the 2010 Electoral Act. Such audited return is to be signed by the political party auditors and countersigned by the party chairman who shall swear to an affidavit as to the correctness of the contents of the return. See s. 92 (2) and (3).

46 See s. 92 (6) of the Electoral Act.

47 See s.92 (8) ibid.

48 Osita Okechukwu, Missing Gap in the 2010 Electoral Act, The Guardian (Nigeria), 28 August 2010, p. 56. 
Yahaya Kwandev Dr Okwesileze Nwodo ${ }^{49}$ that section 7(2)c of the Constitution of the Peoples Democratic Party $2006^{50}$ is binding on the party and imposed an obligation on the party to adhere to the rotation and zoning of the Nigerian presidency. Even though the court refused to issue the orders sought to bar President Jonathan from contesting the primaries of the party on the grounds that s. 87(9) contemplates only candidates to a primary election, it is the binding status of the party's constitution that is of considerable importance. If political parties are private bodies it will be in order to allow members seek redress for infractions of their constitution. In reality they are public bodies and INEC has a constitutional duty to ensure strict compliance with the party constitutions. ${ }^{51}$

The need for effective regulation is evident in the Uwais Report which recommended the unbundling of the INEC by the establishment of a number of other regulatory agencies ${ }^{52}$ including the establishment of a Political Parties Registration and Regulatory Commission. ${ }^{53}$ The duties of the proposed Commission would include the power to register political parties; monitor the organization and operations of political parties including their finances; arrange for the auditing of the annual accounts of political parties; provide and monitor the rules and regulations for political campaigns. It is implicit from the recommendation that the regulatory function of the Political Parties Registration and Regulatory Commission would be deeper and more extensive over the affairs of political parties. The establishment of a regulatory agency charged with the effective regulation of political parties is still important as available evidence points to the incapacity and inability of INEC in this regard.

49 Unreported Suit No HC/CV/3691 (Judgment delivered on 10 $0^{\text {th }}$ January 2011). It is important to however note an earlier decision of the Abuja High Court in Alhaji Sani Aminu Dutsinma v Peoples Democratic Party, Unreported Suit No. FCT/HC/CV/2425/2010, (Judgment delivered on $1^{\text {st }}$ December 2010) that while Article 7 (2) (c) of the PDP constitution is legally extant it is not justiciable for the Court to declare the part of the country the presidency is zoned to. Justice Gumi had stated that "The provision of Article 7.2(c) of the 1st Defendant's constitution 2009 as amended recognises the principle of zoning and rotation of party and public elective offices. The said article is subsisting and binding on the party, its organs and members (...)".

50 S. 7 (2) (c) of the PDP Constitution provides that : "In pursuance of the principles of equity, justice and fairness, the party shall adhere to the policy of rotation and zoning of party and public elective offices and it shall be enforced by the appropriate executive committee at all levels.".

51 The trend all over the world is to classify political parties as public bodies which must be regulated. See for example the Australian case of Baldwin v Everingham [1993] 1Qd R 10 17: "On general principles, where an albeit voluntary association fulfills a substantial public function in our society, it may appear indefensible that questions of construction should be beyond judicial resolution, It is one thing to say that a small voluntary association with limited assets, existing solely to serve the personal needs of members should be treated as beyond such supervision; it is another thing to say that a major national orgarnisation with substantial assets, playing a central role in the determination of affairs of a country should be so immune.".

52 The agencies that were to be created from INEC included a Political Parties Registration and Regulatory Commission an Electoral Commission; A Constituency Delimitation Commission and a Centre for Democratic Studies.

53 See Paragraph 2.2.4.8 of the Report, note 2, p. 28. 


\section{Unlimited Judicial Review of Compliance With Constitutional Statutory and Internal Obligations of Political Parties}

This part of the article examines the third proposition on the need for an unlimited judicial review of compliance by Nigerian political parties with their constitutional statutory and internal obligations. It is clear that this proposition is connected to the second proposition examined in the preceding section which recommended a more effective regulation of political parties. To complement the administrative regulation of political parties, it is also important that members of a party are able to seek judicial review of compliance with the constitutional statutory and internal obligations.

As argued above the constitutionalisation of Nigerian political parties characterises them as public institutions. Like other public institutions they are bound to be transparent respect human rights and justify the exercise of their powers which are principles which govern the exercise of the public power that it is formed to compete and if successful exercise. Nigeria is not alone in constitutionalisng political parties. For example section 55(5) of the Constitution of Ghana provides that "The internal organisation of a political party shall conform to democratic principles and its actions and purposes shall not contravene or be inconsistent with this constitution or any other law." This is also the tenor of Article $71 \mathrm{c}$ ) of the Ugandan Constitution.

The consequences of the public status of Nigerian political parties have been a matter of contention in many areas of which the nomination and sponsorship of candidates for electoral competition has been prominent. In the opinion of Oguntade JSC in Ararume $v U g w u^{54}$ :

If the political parties, in their own wisdom had written it into their Constitutions that their candidates for election would emerge from their party primaries, it becomes unacceptable that the court should run away from their duty to enforce compliance with the parties Constitution...An observer of the Nigerian political scene today easily discovers that the failure of the parties to ensure intra-party democracy and live by the provisions of their constitutions as to the emergence of candidates for elections is one of the major causes of the serious problems hindering the enthronement of a representative government in the country. ${ }^{55}$

54200712 NWLR (Pt 1048) p. 367.

55 Ibid 461. See also Muhammed JSC at 497 where it was stated that "it appears that the Legislature has found some lapses or lacunae in the provisions of section 83(2) of the Electoral Act of 1982 under which the case of Onuoha v Okafor (...) and section 23 of the Electoral Act 2003 under which Dalhatu $v$ Turaki (...) were decided respectively. These sections in the 1982 and 2002 Electoral Acts left the issue of substitution of candidates entirely in the hands of political parties without let or hindrance. But when the legislature realized that the political parties were abusing the unfettered powers of 'making' and 'unmaking' of prospective candidates for the political offices to be contested at lection periods, it then decided to re-draft provisions relating to substitution of candidates for the elective offices.". 
It is contended that there are other equally important issues covered by the constitutions of political parties that should be enforced by the Courts. That is not the case presently because the judicial review of compliance with the constitution of political parties appears to be limited to the tenor of s. $87(9)$ of the 2010 Electoral Act which deals with the nomination and sponsorship of electoral candidates. The said section provides that

Nothwhistanding the provisions of the Act or rules of a political party, an aspirant who complains that any of the provisions of this Act and the guidelines of a political party has not been complied with in the selection and nomination of a candidate of a political party for election, may apply to the Federal High Court or High Court of a State or FCT, for redress.

This provision would seem to imply that all other issues covered by the constitution of a political party are outside the purview of Nigerian courts. This impression has been confirmed by recent decisions of the Nigerian Supreme Court- Lado v Congress for Progressive Change $e^{56}$; and PDP v Sylva $a^{57}$ - where the Court declined the invitation to review the nomination of candidates in political party primaries in circumstances in which the Court held are outside the purview of s.87(9) of the 2010 Electoral Act. To understand the true import of Lado and Sylva, we need to return to the development of the political question doctrine in the context of the 1979 Constitution of the Federal Republic of Nigeria and Nigeria's Second Republic which was defined in Onuoha v Okafor ${ }^{58}$, the Supreme Court stated that the political question doctrine in Nigeria as consisting of two principles. One is that '[ $\mathrm{t}] \mathrm{he}$ lack of a satisfactory criteria for judicial determination of a political question is one of the dominant considerations in determining whether a question falls within the category of political questions'. The other is ' $[t]$ he appropriateness of attributing finality to the action of the political department and political parties under the Nigerian Constitution and system of government'. Onuoha continued as good law until the provisions of the 2006 Electoral Act made it appear untenable. In Ararume v INEC ${ }^{59}$ the Supreme Court held that the Peoples Democratic Party did not comply with section 34(2) of the 2006 Electoral Act which required any political party wishing to substitute its candidates to give cogent and verifiable reasons. The political party had substituted the name of Senator Ifeanyi Ararume with that of Engr Charles Ugwuh to contest the gubernatorial election in Imo State. In a short judgment the Court declared that "this case is different from the Onuoha v Okafor case" 60 and that the substance of the case had to deal with the interpretation of s 34(2) of the 2006 Electoral Act. The 1982 Electoral Act in force when Onuoha was decided did not have the equivalent of s 34(2). It was contended that the makers of section 34 (2) of the 2006 Electoral Act intended to resolve the problems

56 (2011) LPELR- SC.157/2011. Hereafter Lado.

57 (2012) LPELR-SC.28/2012. Hereafter Sylva.

58 (1983) NSCC 494.

59 Note 54.

60 See Daily Sun (Nigeria), Friday 6 April 2007. 
created by its predecessors such as the 2002 Electoral Act, which gave wide latitude to political parties to substitute candidates at will. In issue was the question of 'cogent and verifiable reasons.' Presumably the reasons, advanced by the party are to be reviewed by the electoral agency and subsequently by the Court as the Supreme Court did in this case. It is difficult to imagine the reasons of a political party that will satisfy this standard. Is the reason one to be assessed by the court from its standpoint or that of the political party? Will a reason that it made an error suffice? Will the court in assessing the reason(s) admit facts emanating from the primaries? In Ararume it seems that the court was conscious of the fact that the new candidate was the fourteenth candidate in the primaries. If this were so, would the substitution by the second candidate in the primaries have been 'cogent and verifiable' or is the term directed at the general qualifications for candidates set out by sections 66, 107, 137 and 182 of the 1999 Constitution. Whatever the intendment of the phrase, it is clear that it took the question of substitution of candidates from the exclusive preserve of the political party to the review of the electoral agency and ultimately the courts. Should the Supreme Court have demurred in line with its decision in Onuoha? By stating that the two cases are different the Court pointed to the statutory cast of the 2006 Electoral Act, rather than the 1999 Constitution as its authority. It was in the court's opinion a simple case of statutory interpretation. This was also the situation in Onuoha where the Supreme Court in the absence of any statutory or constitutional ouster decided not to intervene in the question of sponsorship of party candidates and held that the 1979 Constitution and s. 83 of the 1982 Electoral Act gave the political party the right to decide which of two or more contending candidates it supports and that it will not intervene in the choice of the party. Amaechi $v$ INEC, ${ }^{61}$ quickly followed Ararume in a way in which it was plausible to argue that the political question doctrine was in retreat if not dead. ${ }^{62}$

A facial reading of s. 87(9) of the 2010 Electoral Act would support a contention that it is a legislative affirmation of Ararume and Amaechi that complaints about political party candidates are justiciable. Unfortunately the Supreme Court has held otherwise. In Lado the Supreme Court held that once a dispute arises as to which of two primaries conferred a right of candidature aspirants to represent a political party the matter was no longer in the contemplation of s. 87 of the 2010 Electoral Act because of the fact that the possibility of two primaries is not provided for in s. 87 of the Electoral Act. Onnoghen JSC who read the lead judgment of the Court recounted the principle laid down in Onuoha as establishing the fact that the question of a political party candidate is in the nature of a political question which is not justiciable before a court of law. The Court pointed out that s. 34 of the 2006 Electoral Act tampered with the absolute power of a political party only to the extent and in relation to the change/substitution of a nominated candidate and that the said section did not interfere with

61200718 NWLR (Pt. 1065) 170.

62 See Enyinna Sodienye Nwauche, Is the End Near for the Political Question Doctrine in Nigeria: in Christina Murray / Charles Manga Fombad (eds.), Fostering Constitutionalism in Africa, Pretoria 2009 , p.31. 
nor did it alter or modify the principle that the question as to who is a candidate of a political party for any election is a political question within the domestic jurisdiction of political parties and consequently not justiciable.

This appears to be a startling interpretation because it would appear that Lado completely abrogates the provisions of s. 87(9) of the Electoral Act. Thus even if a candidate were to contest the outcome of a single primary, such a claim would not be justiciable. It is interesting to note that the question of double primaries also arose in Nagogo $v$ Congress for Progressive Change $^{63}$ in which the lead judgment of Peter-Odili JSC extensively reviewed the conduct of primaries of a political party and decided that a particular primary was the authentic primary of the party. Clearly if the court had followed its decision in Lado- which was not even mentioned in the Lead judgment- the matter would have been considered as a political question because it did not fall within the contemplation of s. 87 of the Electoral Act. Lado and $\mathrm{Na}$ gogo are at odds with the latter being, in my opinion, a proper interpretation of s. 87(9) of the 2010 Electoral Act. Lado throws Nigeria back to the Onuoha era with the consequence that the political question doctrine appears to be on the ascendancy. In $P D P v S y l v a^{64}$, the Supreme Court followed Onuoha in deciding that "the nomination or sponsorship of a candidate for election is a political matter within the discretion of the party" but sought to distinguish the stage of primary elections from nomination and sponsorship of elections as the pre-primary election stage. This distinction appears inevitable because of the opinion of the lead judgment in Sylva written by Rhodes-Vivour JSC:

...where the political party conducts its primary and a dissatisfied contestant at the primary complains about the conduct of the primaries the courts have jurisdiction by virtue of the provisions of section 87(9) of the Electoral Act to examine if the conduct of the primary election was conducted in accordance with the parties constitution and Guidelines. This is so because in the conduct of its primaries the courts will never allow a political party to act arbitrarily or as it likes. A political party must obey its own constitution.

From the facts of Sylva it is difficult to characterise the complaints of being excluded from a primary election as well as cancellation of primary election as a pre-primary election matter. Former Governor Timipre Sylva was adjudged the candidate of the Peoples Democratic Party (PDP) in January 2011 for elections scheduled for April 2011. After the nomination but before the elections Governor Sylva convinced Nigerian courts that his term of office did not end in 2011 but in 2012 because his term of office began when he took a second oath of office in 2008 having won the rerun elections in 2008 after his 2007 elections were annulled for irregularities. His contention that his January 2011 nomination still subsisted and that the process of nominating a new candidate in November 2011 breached s. 33 of the Electoral Act was rejected by the Supreme Court which held that the January 2011 nomination was annulled by 
the extension of Governor Sylva's tenure. To hold that these two issues amounted to a preprimary issue is to stretch the argument too far. The Supreme Court reviewed the decision of the PDP and came to a conclusion that the party was right to disregard the January 2011 nomination and that it was within the rights of the party to exclude Governor Sylva. The Supreme Court also held that Governor Sylva could not take advantage of s. 87(9) since he did not contest the primaries. To arrive at this conclusion the Court defined the term 'aspirant' - used in s. 87(9) of the 2010 Electoral Act- as a 'person with a strong desire to achieve a position of importance or to win a competition' and held that an aspirant is a person who contested an election. It is clear that this interpretation is farfetched since it ignores the fact that a person who is wrongfully excluded from a political party primary also aspires to a position but may have been denied the opportunity to contest the election. The holding that an 'aspirant' must have contested primary elections to have the standing to complain is to invite political parties to willfully exclude candidates from primary elections and then turn around to urge a court to discountenance complaints of exclusion on the basis of a lack of standing. In totality the Sylva court was torn between abiding with Onuoha in view of Ararume and Amaechi on one hand and the clear terms of s. 87(9) of the 2010 Electoral Act on the other hand. To hold that nomination and sponsorship of a party candidate is a preprimary matter would appear to be a clear indication of the strength of Onuoha. The Supreme Court labored to defer to the decision of the political party to exclude Sylva. It is worthwhile to wonder whether Nagogo is an aberration except that it is the latest Supreme Court judgment on the matter and it may indicate a move away from Onuoha. Be that as it may it is important for the Supreme Court to realize that the review of the nomination and sponsorship of electoral candidates is crucial to the survival of political parties. In this regard s. 87(9) ought to be welcomed and interpreted as broadly as possible. As stated above it is important that the activities of political parties, beyond the selection of electoral candidates are also subject to judicial review. Comparative perspectives indicate that this is the trend in other African countries. For example section 55(5) of the 1992 Constitution of Ghana provides that "The internal organisation of a political party shall conform to democratic principles and its actions and purposes shall not contravene or be inconsistent with this constitution or any other law." 65 Accordingly members of political parties can challenge decisions of their party on the basis of a constitutional platform. It needs be stated that the absence of such clear constitutional basis for the review of compliance with party constitutions is not fatal. The fact that a political party is bound by human rights is as important in this regard as is the fact that members of political parties can enforce their rights against a political party. Enforcing a party constitution would go a long way in ensuring that human rights of party members are respected.

65 This is also the tenor of Article 71 (c) of the Ugandan Constitution. 


\section{A Principled Adjudiciation of Electoral Disputes}

As stated in the introduction one of significant post 2011 election issues is the strict interpretation by the Nigerian Supreme Court of the constitutional time limit stipulated by s. $285(6)^{66} \&(7)^{67}$ of the 1999 constitution for the resolution of election petitions. In a series of judgments- Shettima v Goni ${ }^{68}$; Marwa v Nyako, ${ }^{69}$ Ogboru v Uduaghan ${ }^{70}$; and PDP v Okoroch ${ }^{71}$ the Supreme Court has refused to extend, elongate, expand or stretch the time limit for delivery of judgments of election appeals tribunal or judgments of the court of appeal on appeals from election tribunals. Any appeals on judgment delivered outside the constitutionally stipulated time has been struck out by the Court. Even the plea that the Supreme Court, resort to its powers in s. 22 of the Supreme Court Act ${ }^{72}$ was turned down in Shettima v Go$n i .^{73}$ The position of the Supreme Court was not assuaged by the fact that the Court in ordering a retrial of election petitions as in Ogboru $v$ Uduaghan ${ }^{74}$ occasioned the determination of election petitions outside the constitutionally stipulated time limit. Even when petitioners alleged, as they did in Amadi v INEC 75 that the Court of Appeal 'deliberately' fixed the hearing of the appeal filed before it on a day that the prescribed time expired in order to shut out the appellant, the Court stood its ground and described the provisions of section 285(7) as "the Rock of Gilbraltar or Mount Zion which cannot be moved." 76 Commenting on the decision of the Court, Iwilade Akintayo argues that:

66 An election tribunal shall deliver its judgment in writing within 180 days from the date of the filing of the petition.

67 An appeal from the decision of an election tribunal or court shall be heard and disposed of within 60 days from the date of the delivery of judgment of the tribunal.

68 [2012] All FWLR (Pt. 609) p. 1007.

69 Unreported consolidated appeals in SC. 141/2011; SC./766/2011; SC.267/2011; SC. 282/2011; SC. 365/2011 and SC.357/2011 delivered on Friday 27January 2012.

70 Unreported Consolidated Suit No SC.18/2012; SC.18A/2012, judgment delivered on 2 March 2012.

71 Unreported Suit No. SC17/2012. Judgment delivered on 2March 2012.

72 Section 22 of the Supreme Court Act Cap S15 Laws of the Federation of Nigeria provides that: "The Supreme Court may, from time to time make any order necessary for determining the real question in controversy in the appeal, and may amend any defect or error in the record of appeal, and may direct the court below to inquire into and certify its findings on any question which the Supreme Court thinks fit to determine before final judgment in the appeal and may make any interim order or grant any injunction which the court below is authorized to make or grant and may direct any necessary inquiries or accounts to be made or taken and generally shall have full jurisdiction over the whole proceedings as if proceedings had been instituted and prosecuted in the Supreme Court as a court of first instance and may re-hear the case in whole or in part or may remit it to the court below for the purpose of such re-hearing or may give such other directions as to the matter to which the court below shall deal with the case in accordance with the powers of that court.".

73 Note 68.

74 Note 70.

75 Unreported Suit No SC.467/2011. Judgment delivered on 3 February 2012.

76 Ibid, p. 21. 
"The very foundation of a State's authority is what is being questioned in election petitions. Further, the petitions are a means of seeking to find out whether the persons exercising state authority are doing so with the mandate of the people...that makes an election petition a fundamentally substantive exercise that cannot be subsumed, or reduced in significance, by a resort to merely procedural provisions like the type contained in section 285(6).",77

A principled adjudication of electoral results facilitates and demands a culture of justification of such results. The culture of justification entails a detailed scrutiny of election results to ascertain compliance with extant laws and regulations and serves to legitimize and sustain faith in the democratic process. Without such faith the contestation of power is bound to degenerate into self-serving ends and possibly anarchy. No matter the outcome of a judicial review, it is important that a court engages in a substantive review of electoral disputes. To rely on procedural matters such as time limits as a means of disposing of electoral disputes is to sow doubt on the legitimacy of the electoral and democratic process. Such procedural reviews demean the rule of law encourage electoral rascality and impunity. Political parties may be emboldened to breach their constitutions and stifle internal democracy since their actions would not be subjected to substantive review.

There is little doubt that the Supreme Court has struck an expedient tone in these judgments and rather than being principled in its decision the court has chosen to toe the line of pragmatism in the unprecedented line of cases discussed above. One cannot but remember the US Supreme Court in Bush v Gore ${ }^{78}$ and draw parallels as to how the judgments of the two courts intervened in the political process on political rather than legal grounds. An extensive review of the judgments of the Nigerian Supreme Court reveals no principled justification of its decisions beyond a desire to ensure a strict interpretation of the 1999 Constitution. We are left therefore to hazarding guesses. Institutional protection and integrity appears to be a likely reason. In the wake of substantial corruption scandals involving appellate courts in respect of election petitions from the 2007 general elections, it is plausible that the Court was wary of substantive review of the 2011 election petitions that engendered the allegations of sleaze that embroiled former principal officers of the Nigerian judiciary. ${ }^{79}$ In the long run however the decisions of the Supreme Court could do more harm to the political process than envisaged. Political parties will be encouraged to engage in brinkmanship rigging and abuse of the rule of law if the Supreme Court does not retreat from this line of reasoning.

77 Iwilade Akintayo, "Supreme Court's Judgment on election petitions time limit: Issues Arising" The Guardian (Nigeria), Tuesday 7 August 2012.

78531 US 98 (2000).

79 See "Katsina-Alu \& Ayo Salami: Scandal of Judicial Corruption", available at www.vanguardngr. com/2011/02/katsina-alu-ayo-salami-scandal-of-judicial-corruption (last accessed on 27 November 2013). 


\section{Conclusion}

The four propositions argued in this paper are critical in enabling Nigerian political parties fulfill their potential especially as the 2015 general elections approach. The issues discussed in this paper demand that yet another process of electoral reform should be initiated. It will be wise to anchor this reform on the road map set out by the Uwais Report. It is also critical to draw the attention of the Nigerian judiciary to the importance of the principled adjudication of electoral disputes.

This paper has examined four propositions that could enhance the institutionalization of political parties and their role in democratic consolidation in Nigeria. The factual context of Nigeria has provided rich evidence of the internal and externals aspects of party institutionalization. The fact that three out of the four propositions examined the external aspects of party institutionalization is indicative of a belief that structural and attitudinal issues of the interaction of political parties with the institutions and organs of the Nigerian society could significantly impact on the development of the parties. The third and fourth propositions that discuss the role of the judiciary in the institutionalization of political parties draw attention to the importance of the judiciary to party institutionalization in Nigeria. There is need therefore for more scholarly reflection on the role of the judiciary in party institutionalization in Nigeria and the rest of Africa as democracy solidifies. Other aspects off party institutionalization in Nigeria and Africa that require further reflection include the extent of public funding of political parties; and the consequences of the constitutionalisation of political parties. 